\title{
Patterns of activity rhythms of invasive coypus Myocastor coypus inferred through camera-trapping
}

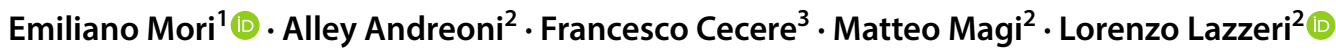

Received: 30 March 2020 / Accepted: 4 July 2020 / Published online: 14 July 2020

(c) Deutsche Gesellschaft für Säugetierkunde 2020

\begin{abstract}
Studies on activity rhythms are pivotal for the management of invasive alien species, as they provide basic insights into species basic ecology and may increase the success of control programs. The coypu Myocastor coypus, introduced from South America for fur farms, has become one of the most invasive rodents in Europe. Introduced coypus may affect crop productions, as well as natural vegetation and the breeding success of wading birds. In this study, we examined activity data collected through intensive camera-trapping in three Italian areas, including two natural areas in Northern and Central Italy, and a suburban area in Central Italy. Coypus were mostly diurnal in areas characterised by low predator pressure and, at night, they are mostly active in bright moonlight. Conversely, where predators, human pressure or numerical control programmes are present, coypus remarkably shift their behaviour towards crepuscular and night hours. In these last areas, nocturnal activity increased as moonlight decreased, possibly to reduce predation risk or encounters with humans. Where winter temperature are low, diurnal habits may have developed as a physiological adaptation and a strategy to preserve energy, potentially achieving a cost/effective thermal balance.
\end{abstract}

Keywords Camera trap $\cdot$ Invasive species $\cdot$ Moon phases $\cdot$ Myocastor coypus $\cdot$ Semi-aquatic mammal $\cdot$ Seasonal overlap

\section{Introduction}

Invasive alien species represent one of the main causes of the current global biodiversity crisis (Genovesi 2011; Bellard et al. 2016). Biological invasions may shape and modify native biodiversity communities, by means of impacts including competition, ecological alterations, economic

Handling editor: Adriano Martinoli.

Electronic supplementary material The online version of this article (https://doi.org/10.1007/s42991-020-00052-8) contains supplementary material, which is available to authorized users.

Emiliano Mori

moriemiliano@tiscali.it

1 Consiglio Nazionale Delle Ricerche, Istituto Di Ricerca Sugli Ecosistemi Terrestri, Via Madonna del Piano 10, 50019 Sesto Fiorentino, Florence, Italy

2 Dipartimento Di Scienze Della Vita, Università Degli Studi Di Siena, Via P.A. Mattioli 4, 53100 Siena, Italy

3 Riserva Naturale, Agriturismo e Oasi WWF "Le Bine", Strada Bine 1424, 46011 Acquanegra Sul Chiese, Provinces of Mantova and Cremona, Italy and health costs (Mack et al. 2000; Mazza et al. 2014). A detailed knowledge on the spatiotemporal behaviour of invasive alien species is pivotal to implement the success of removal operations (Bertolino et al. 2020; Capizzi 2020). Accordingly, assessing when alien species are active may help timing operations of numerical control, so to increase success of management interventions (Mazza et al. 2019; Andreoni et al. 2020). Camera-trapping have been widely reported to be a reliable tool to assess vertebrate activity rhythms (Ridout and Linkie 2009; Monterroso et al. 2013; Torretta et al. 2017; Mori et al. 2020a), as they provide similar results to radio-tracking (Lashley et al. 2018) when at least 30-50 detections are available (Ridout and Linkie 2009).

Among invasive vertebrates, the coypu Myocastor coypus (Molina, 1782) is a large semiaquatic rodent native to the subtropical regions of South America (Woods et al. 1992; Carter and Leonard 2002). In the XX century, the coypu has been widely traded and introduced outside of its native range for fur-farming (Carter and Leonard 2002). In Italy, first coypus in the wild were observed in the 1960s and it now occurs in all regions, but for Aosta valley, including major islands (Sicily, where no observation are available since 3 years, and 
Sardinia: Bertolino and Cocchi 2018). On one hand, impacts and spatial behaviour of this species are widely known. Coypus select waterways with weak streams and dense riparian vegetation (Woods et al. 1992; D'Adamo et al. 2000; Roviani et al. 2020), but they may also colonise polluted habitats and urban areas too (Meyer et al. 2005; Corriale et al. 2006). Where introduced, they may affect native environments by (1) feeding on natural vegetation (Prigioni et al. 2005; Marini et al. 2013) and crops (D'Adamo et al. 2000; Panzacchi et al. 2007), (2) crashing the eggs of waterbirds using floating nests as resting sites (Angelici et al. 2012; Bertolino et al. 2012) and (3) burrowing in riverbanks (Carter and Leonard 2002). Furthermore, a sanitary impact by this rodent is also recorded, as it represents a reservoir for several zoonoses (Mènard et al. 2001; Nardoni et al. 2011; Zanzani et al. 2016). On the other hand, data on activity rhythms of this species are scanty, thus potentially limiting the success of killings for numerical control. Coypus are reported to be mostly nocturnal, but with some diurnal activity in cold season and where supplemental food is provided by humans, according to studies in captivity (Lomnicki 1957; Gosling 1979), based on indirect signs of presence (Gosling et al. 1980; Chabreck 1982), on very few radio-tagged individuals ( $N=6$ : Palomares et al. 1994; Meyer et al. 2005), or for a low amount of time (e.g., 7 days in winter: Palomares et al. 1994). In Italy, the coypu is excluded from protected species (National Law 157/1992). Plans of numerical control of this large rodent are widespread in Northern and Central Italy, mostly involving direct captures with cages or direct killing through firearms (Bertolino and Cocchi 2018).

Human activity and predator presence are reported to influence activity rhythms of prey species, including rodents (Yoneda 1983; Mohr et al. 2003; Patergnani et al. 2010). In our work, we assessed the seasonal variation of patterns of activity rhythms of the coypu in three areas of Italy characterised by contrasting habitat composition, through intensive camera-trapping. We predicted that (1) activity of coypu would change seasonally, (2) coypus would be mostly crepuscular and nocturnal in our study areas, (3) diurnal behaviour would be more evident in suburban areas, where predation risk is suggested to be the lowest and where humans are known to feed coypus, with respect to rural ones.

\section{Materials and methods}

\section{Data gathering}

During the Italian national lockdown due to SARS-CoV-2 pandemic outbreak, we carried out a survey on the cameratrapping Facebook group "Fototrappolaggio Naturalistico" (https://www.facebook.com/groups/216574218424779 , $N$ followers $=9765$ ) and we asked whether someone has camera-trapped a good amount of coypu records $(N \geq 30$ per season: Lashley et al. 2018), to draw patterns of activity rhythms. Successful camera-trapping of semiaquatic mammals may be difficult because of their lower body temperature, which may fail in triggering camera sensors (Lerone et al. 2015, for the Eurasian otter Lutra lutra). Amongst 28 respondents, only three provided us with a relevant amount of videos from three study areas. Other 12 carried out camera-trapping to assess presence and densities of other species (e.g., the wolf Canis lupus, the wild boar Sus scrofa, small carnivores) and deleted most of their coypu videos.

\section{Study areas and camera-trapping sampling design}

We obtained data from three sites.

1. Site 1 ("Oasi WWF Le Bine", provinces of Mantova and Cremona, N Italy: $45.14^{\circ} \mathrm{N}-10.44^{\circ} \mathrm{E}, 24-26 \mathrm{~m}$ a.s.l., $96 \mathrm{ha}$ ), along the Oglio river banks. This area is currently covered with arboreal cultivations (29\%), fallows (22\%), hygrophilous woodland (19\%), water mirrors $(16 \%)$, weeds $(10 \%)$ and riparian vegetation $(4 \%)$ (Cecere and Ravara 2011; Agapito Ludovici et al. 2012). The thermal regime shows a winter minimum in January $\left(2{ }^{\circ} \mathrm{C}\right)$ and a summer maximum in July $\left(22^{\circ} \mathrm{C}\right)$, with a mean annual temperature of $13{ }^{\circ} \mathrm{C}$. Precipitations show instead an annual average of $829 \mathrm{~mm}$, with a peak (about $95 \mathrm{~mm}$ ) in October (Agapito Ludovici et al. 2012). Camera trapping in 30 ha of this area is ongoing since May 2015, with three camera traps placed along water mirrors (camera trap models: ScoutGuard ${ }^{\circledR}$ SG550-12mHD, ScoutGuard ${ }^{\circledR}$ SG2060-X and BG962-30W), kept constantly active throughout the year. Apart from a single house within the study area, the straight distance Site 1-nearest settlement (including sheds, barns and industrial areas) was $539 \mathrm{~m}$, the one Site 1-nearest residential area (village or town) was $1900 \mathrm{~m}$. At least 50-60 coypus occurred in the study area at the time of field work.

2. Site 2 (Bagno a Ripoli, province of Florence, C Italy: $43.74^{\circ} \mathrm{N}-11.31^{\circ} \mathrm{E}, 125-139 \mathrm{~m}$ a.s.l., 26 ha), along the Ema river banks in the Florence metropolitan area. This site is mostly covered with cultivations (73\%), followed by deciduous woodland $(12 \%)$, irrigation canals $(10 \%)$ and human settlements (5\%). The thermal regime shows a winter minimum in January $\left(2{ }^{\circ} \mathrm{C}\right)$ and a summer maximum in August $\left(29^{\circ} \mathrm{C}\right)$, with a mean annual temperature of $14.5^{\circ} \mathrm{C}$. Precipitations show instead an annual average of $870 \mathrm{~mm}$, with a peak (about $115 \mathrm{~mm}$ ) in November (cf. Giuntini 2019). Camera trapping in this area has been ongoing since January 2019, with three camera traps (Multipir $12^{\circledR}$, Scouting Camera) placed on trails along irrigation ditches and kept constantly active throughout the year. The straight distance Site 2-nearest 
settlement (including sheds, barns and industrial areas) was $150 \mathrm{~m}$, as well as the one Site 2-nearest residential area. A total of 25-30 coypus were counted in this area at the time of our field work.

3. Site 3 (Villa Ceccolini, province of Pesaro-Urbino, C Italy: $43.86^{\circ} \mathrm{N}-12.85^{\circ} \mathrm{E}, 62-75 \mathrm{~m}$ a.s.l., 4 ha). This site is located in a rural area, and includes a small hygrophilous deciduous woodland (78\% of the study area), with a pond $(16 \%)$ surrounded by riparian vegetation $(4 \%)$, and forest glades (2\%). The thermal regime shows a winter minimum in February $\left(3^{\circ} \mathrm{C}\right)$ and a summer maximum in July $\left(24^{\circ} \mathrm{C}\right)$, with a mean annual temperature of $13^{\circ} \mathrm{C}$. Precipitations show instead an annual average of $828 \mathrm{~mm}$, with a peak (about $99 \mathrm{~mm}$ ) in October (Farina and Cavitolo 2016). Camera trapping in this area has been ongoing since January 2020, with two camera traps (Apeman ${ }^{\circledR}, \mathrm{H} 70$ ) kept constantly active. The straight distance Site 3-nearest settlement (including sheds, barns and industrial areas) was $202 \mathrm{~m}$, the one Site 3-nearest residential area (village or town) was $1110 \mathrm{~m}$. About $8-10$ coypus were present in the pond at the time of our field work.

In all study sites, no control programme for the coypu was currently ongoing. In Site 2, some coypu individuals were killed through firearms in 2018. The main predators of the coypu are the red fox Vulpes vulpes, which occurs on all the study sites, and the grey wolf Canis lupus, present in Sites 2 and 3 (Berzi 2015; Supplementary File 1 ), which mostly prey on coypu in winter (Ferretti et al. 2019). As to Site 1 and Site 2, we have data for all the four seasons, whereas we have only winter data for Site 3. In all sites, camera-traps were opportunistically placed on the coypu trail around ponds, ditches and rivers. Cameratrap stations were separated from one-another by at least $500 \mathrm{~m}$ in straight line, so to reduce pseudo-replication bias (O'Connell et al. 2011), so to cover the entire water bodies hosting coypus in the three study areas. Accordingly, with this inter-camera distance, we put the higher number of possible camera traps in each study area. Cameras were placed at $\sim 130-150 \mathrm{~cm}$ from the ground level and were activated $24 \mathrm{~h}$ /day, to take one video every time an animal passed in front of the camera trap. Checks occurred once every 10 days to download data and replace empty batteries. We detected no significant spatiotemporal bias in sampling across different seasons (Rayleigh test, $Z=13.25$, $p=0.08$ ) (O'Connell et al. 2011). As to Site 1, we detected no significant difference in circadian rhythms across years and across the same seasons in different years (MardiaWatson-Wheeler tests: $0.018<W<0.159 ; p>0.10)$. Thus, we pooled together all coypu videos occurring in the same seasons in different years for our analyses (Mori et al. 2020a). We defined the night as the period included between $1 \mathrm{~h}$ after sunset and $1 \mathrm{~h}$ before sunrise (Carnevali et al. 2016).

\section{Patterns of activity rhythms}

We divided the study period of each study area (Site 1, 2015-2020; Site 2, 2019; Site 3, 2020) into four astronomical seasons (spring, summer, winter and autumn). Analyses were carried out on both total and seasonal scales. We defined activity outside burrows as the cumulate period animals spend outside dens, regardless of their behaviour (Meredith and Ridout 2014; Lashley et al. 2018). For all coypu videos, we reported the date and the solar hour of capture (directly shown on the video) on a dataset. The use of solar hour allows a better evaluation of activity patterns as, differently from "legal hour", it is defined by the position of the sun in the sky regardless to the local time which varies among seasons. We limited pseudoreplication bias by counting as one "independent event" all coypu videos taken by the same camera trap in less than $30 \mathrm{~min}$ (Monterroso et al. 2014; Torretta et al. 2017). When more than one coypu video was recorded by the same camera trap in $\leq 30 \mathrm{~min}$, we kept in our dataset only one record, placed in the mid-time between the first and the last video.

We used the software R (version 3.6.1., R Foundation for Statistical Computing, Wien, Austria: www.cran.r-proje ct.org), package overlap (Meredith and Ridout 2014) to assess activity rhythms and patterns of inter-seasonal temporal overlap. We estimated the coefficient of overlapping $(\Delta)$ between temporal activity patterns of all pairwise season combinations in the same study area. We also calculated overlap among activity patterns in the same season in different study sites. The coefficient of overlapping ranges between 0 (no overlap) and 1 (total overlap: Linkie and Ridout 2011; Meredith and Ridout 2014). We calculated the $\Delta_{4}$ estimator when the smallest sample of each pairwise comparison was $>75$ records, $\Delta_{1}$ if at least one of the sample of each pairwise comparison was $<75$ records (Linkie and Ridout 2011; Meredith and Ridout 2014). The 95\% confidence intervals (hereafter, 95\% CI) of the coefficient estimator were estimated using 10,000 bootstrap replicates (Dias et al. 2019). Overlap was "intermediate" with $\Delta$ included between 0.50 and 0.75 was considered as, "high" with $\Delta>0.75$, "very high" with $\Delta>0.90$ (Monterroso et al. 2014; Mazza et al. 2019). The Mardia-Watson-Wheeler W-test (MWW test, $U^{2}$ ) was used to compare inter-seasonal overlap between different study sites, and same-season overlap between each site pair (Monterroso et al. 2014); it was calculated through the R package circular (Lund et al. 2017). We also tested whether sky brightness affected the activity of the coypu by classifying surveyed nights according to moon phases and epact: (1) epact days $=0-3,26-29$; (2) epact days $=4-6$, $21-25$; (3) epact days $=7-9,17-20$; (4) epact days $=10-16$ 
(Mori et al. 2014). We performed a chi-squared test on the numbers of videos recorded during each of these moonlight periods, to assess if they were uniform throughout epact days (Mori et al. 2014, 2020a).

\section{Results}

In our analyses, we included a total of 447 independent records from Site 1 (autumn, $N=174$; winter, $N=78$; spring, $N=137$; summer, $N=58$ ), 188 from Site 2 (autumn, $N=42$; winter, $N=60$; spring, $N=43$; summer, $N=43$ ), 72 from Site 3 (winter only: Supplementary File 2), for a total of 5198 camera trap-nights.

Annual patterns of temporal rhythms at Sites 1 and 2 showed that the peak of coypu activity occurred in crepuscular hours (Site 1), at night in suburban ones (Site 2). Overlap of annual active patterns between Sites 1 and 2 was intermediate, i.e., $60 \%\left(\Delta_{4}=0.60,95 \%\right.$ CIs $\left.0.57-0.71\right)$. Inter-seasonal overlaps of activity rhythms ranged between intermediate $(\Delta=0.55)$ to high values $(\Delta=0.81)$ in Site 1 (Fig. 1) and Site 2 (Fig. 2). Particularly, in Site 1, the highest overlap occurred between winter and spring, i.e., when most of the watercourses are frozen and coypus are mostly diurnal. In Site 2, overlap levels were always high, except for pairwise comparison involving autumn, showing intermediate overlap levels.
We detected no significant difference in pairwise seasonal overlaps between study sites (MWW tests: $0.0417<U^{2}<$ $0.1528, p>0.05)$.

Same-season overlaps of temporal activity across study sites (Fig. 3) ranged between $49 \%(\Delta=0.49)$ and $77 \%$ $(\Delta=0.77)$. The overlap winter-winter between Sites 2 and 3 was significantly higher than the overlaps winter-winter between both sites and Site 1 (MWW test: $U^{2}=0.2452$, $p>0.03)$.

Coypus avoided darkest nights in spring and summer, as well as on the total survey period, at Site 1. Conversely, this rodent avoided bright full moon nights at Sites 2 and 3 only in winter; in other seasons, its activity rhythms did not depend on moon phases (Table 1).

\section{Discussion}

Our work showed the result of a pilot study on the activity rhythms of the coypus in three study areas characterised by different environmental features. We are aware of the limits related to small sample sizes (i.e., three areas, with at max three camera traps/site), but first results are suggestive and in line with behaviour of other rodent species with changing predation pressure and human activity (Yoneda 1983; Mohr et al. 2003).

Differently from radio-tracking, camera-trapping is intrinsically limited by the imperfect detectability of animals
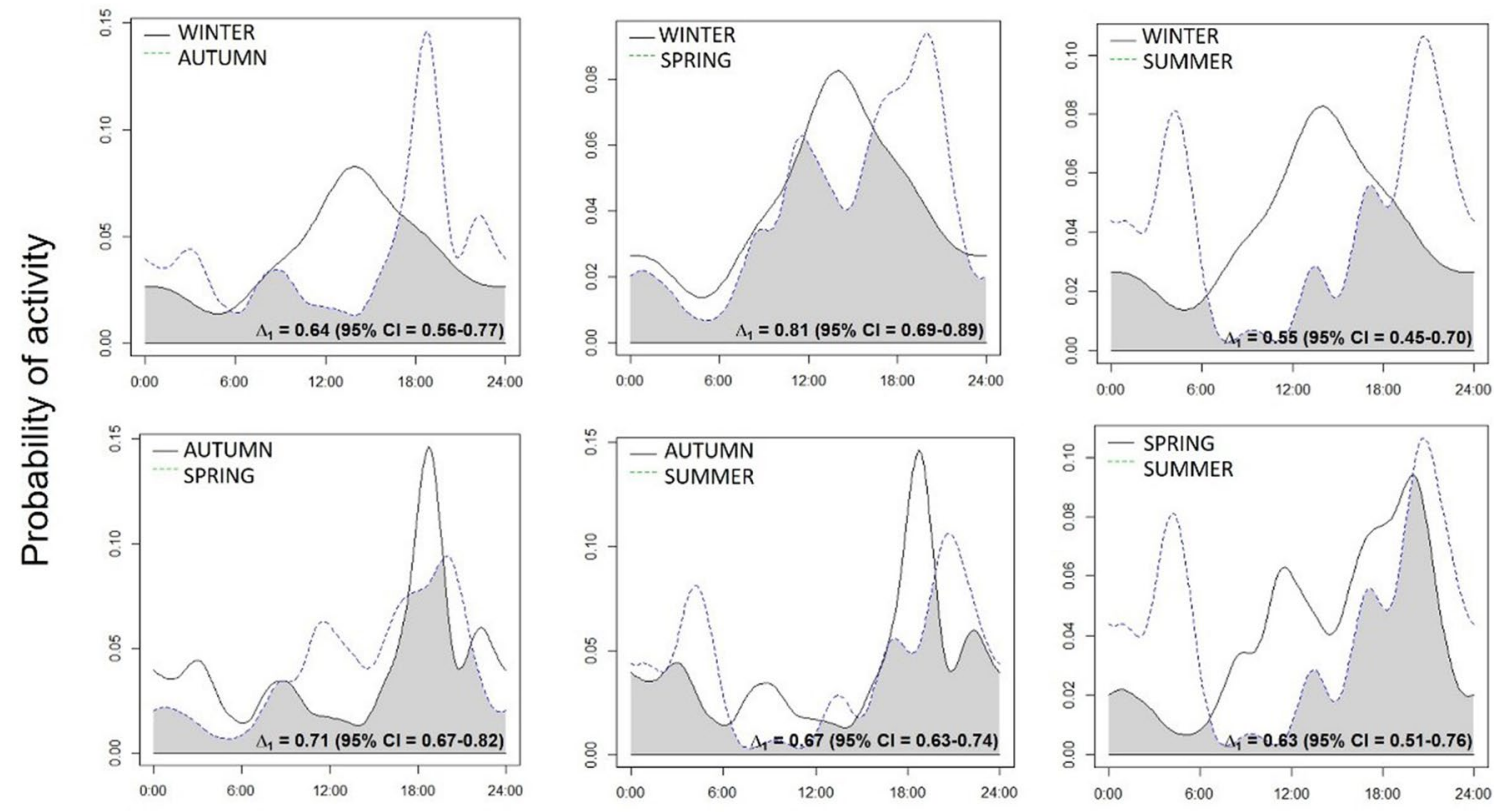

Time of the day

Fig. 1 Inter-seasonal activity patterns of the coypu in Site 1 (Oasi WWF "Le Bine"). Coefficients of temporal overlap and 95\% relevant CIs are reported at the bottom of each graph. The mean value of coefficient of overlapping is represented by the light grey area under the curves 

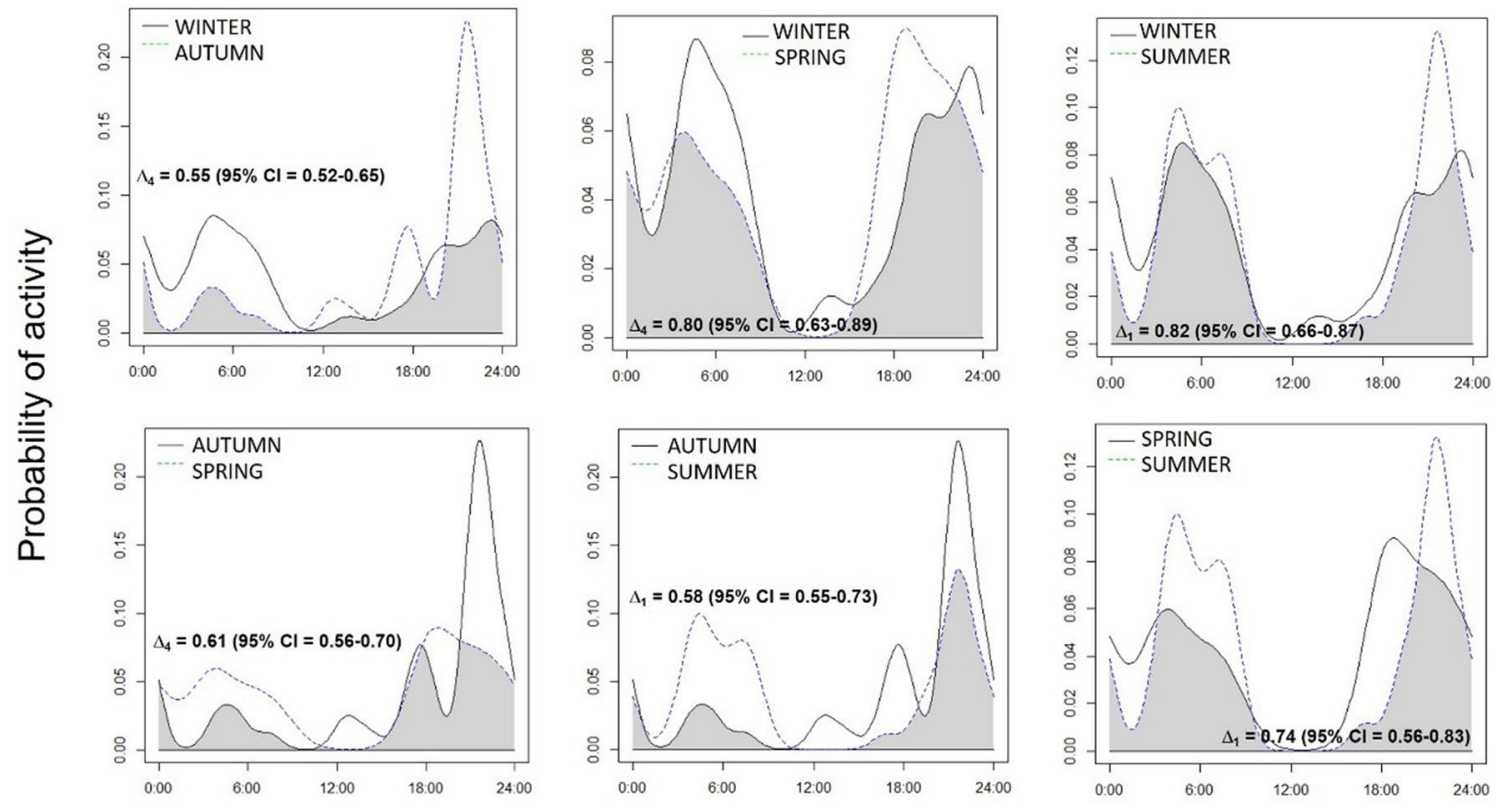

Time of the day

Fig. 2 Inter-seasonal activity patterns of the coypu in Site 2 (Bagno a Ripoli). Coefficients of temporal overlap and 95\% CIs are reported. The mean value of coefficient of overlapping is represented by the light grey area under the curves
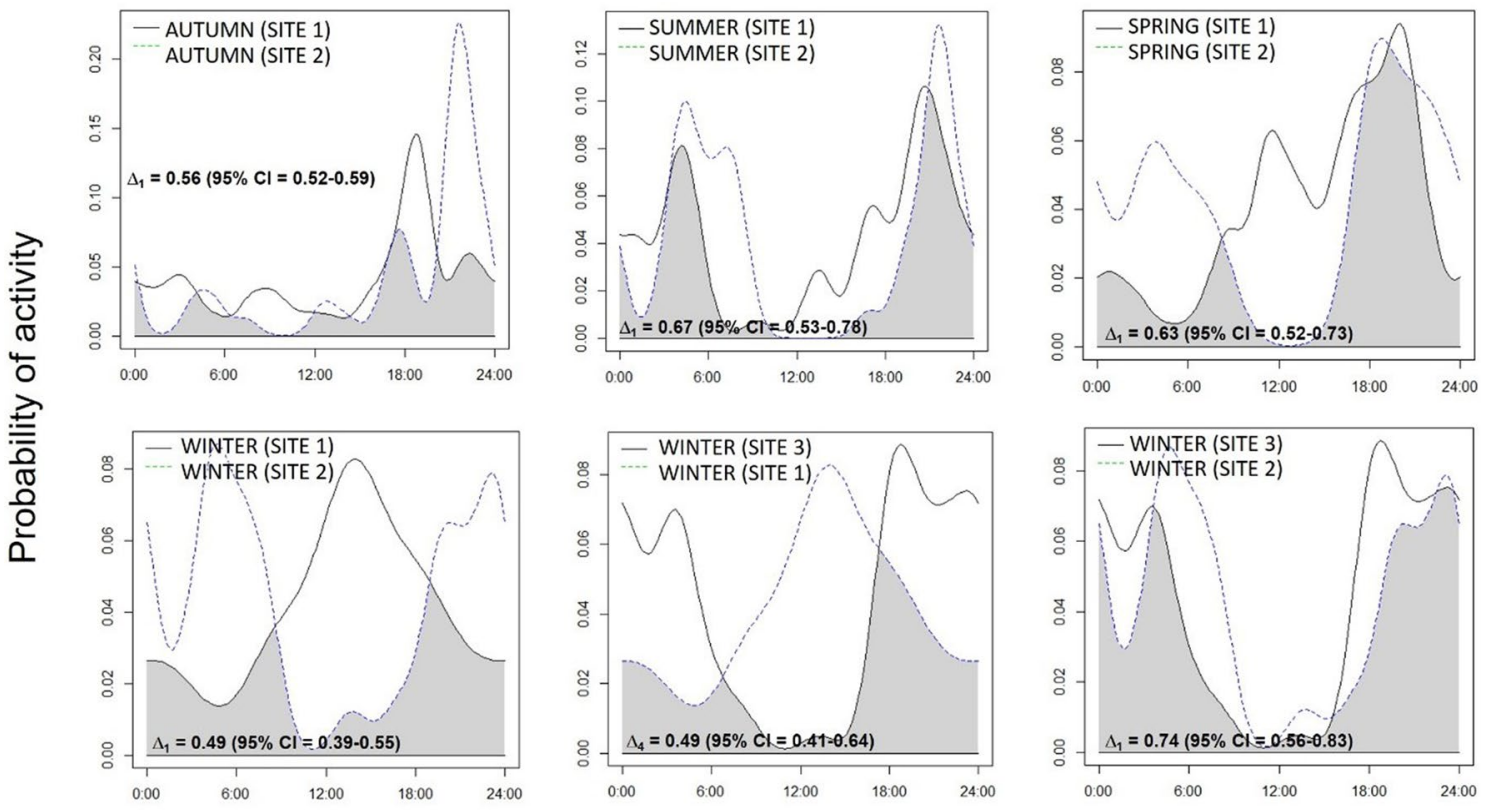

Time of the day

Fig. 3 Same-season overlap patterns of the coypu across study sites. Coefficients of temporal overlap and 95\% CIs are reported. The mean value of coefficient of overlapping is represented by the light grey area under the curves

(Burton et al. 2015). However, a number of recent works has shown that it may provide reliable estimates of activity rhythms (Meredith and Ridout 2014), even when local abundance of species is not available (Monterroso et al. 2013; Lashley et al. 2018; Chen et al. 2019). This is quite a common issue with species living also in concealed habitats 
Table 1 Values of $\chi^{2}$ test ( 3 degrees of freedom) on activity of coypus related to the four moon phases identified (cf. Methods)

\begin{tabular}{llllll}
\hline & Winter & Autumn & Spring & Summer & Year \\
\hline Site 1 & $4.25(0.24)$ & $2.27(0.52)$ & $41.34(<0.001)^{*}$ & $23.28(<0.001)^{*}$ & $20.87(<0.001)^{*}$ \\
Site 2 & $12.11(0.007)^{*}$ & $1.04(0.79)$ & $4.67(0.20)$ & $3.27(0.35)$ & $2.83(0.417)$ \\
Site 3 & $15.33(0.002)^{*}$ & - & - & - & - \\
\hline
\end{tabular}

$p$ values are in brackets: *significant values
(Ridout and Linkie 2009), e.g., the coypu. In our work, coypus showed a great ecological plasticity: they may have adapted their temporal behaviour to seasons within the same site and to local environmental conditions in different sites, thus confirming our prediction (1). This is suggested by the low overlap in annual activity rhythms between the natural site (Site 1) and the suburban one (Site 2). As well, sameseason overlaps between these areas were low, furtherly supporting the hypothesis of different local adaptations.

In the natural area, coypus showed an activity peak at dusk throughout the year. A diurnal peak occurred in winter, i.e., when nights are the coldest (up to $-6{ }^{\circ} \mathrm{C}$ : cf. Agapito Ludovici et al. 2012), and coypus compensate by foraging during daylight. In our study area, diurnal activity decreased in spring and almost disappeared in summer and autumn. The local absence of large wild predators (e.g., the wolf and the golden jackal Canis aureus: Woods et al. 1992), of control plans and of human disturbance may have favoured the coypu activity in daylight hours. This result confirmed data by Davis and Jenson (1960) and by Gosling et al. (1980), who showed that coypu may become diurnal in cold months. Presumably, this adaptation to daylight hours is an adaptive response to limit energy loss and to maintain an adequate food intake at low environmental temperatures (Gosling 1979). Freezing of the surface of water bodies at night may prevent coypus to feed on aquatic vegetation, i.e., the staple of its diet (Prigioni et al. 2005; Marini et al. 2013). Accordingly, food provided to captive coypus throughout the $24 \mathrm{~h}$ cycle restored the crepuscular and nocturnal behaviour of this large rodent (Lomnicki 1957; Gosling 1979). Meyer et al. (2005) also suggested that coypu diurnal behaviour may represent an adaptation to urban environments in Germany, where humans tend to feed this large rodent. Radio-tagged coypus in urban areas in Germany were never detected between midnight and sunrise (Meyer et al. 2005). Conversely, in our suburban study area, activity of the coypu peaked after sunset. Crepuscular and nocturnal behaviour are in line with previous studies in natural environments (i.e., far from human settlements) both in the native and in the introduced range (Chabreck 1982; Palomares et al. 1994), as well as with studies on other large rodents (i.e., porcupines Hystrix spp.: Corsini et al. 1995; Fattorini and Pokerhal 2012), including semiaquatic ones (i.e., the musk rat Ondatra zibethicus and the beaver Castor fiber: Svihla and Svihla 1931; MacArthur 1980; Swinnen et al. 2015;
Pontarini et al. 2019). In our suburban study area, the nocturnal behaviour is maintained by the coypu also in winter, as temperatures of this area rarely go below $0{ }^{\circ} \mathrm{C}$ (Giuntini 2019), which may not affect the commonest locomotor pattern of this species (Wood et al. 1992). Moreover, differently from urban location by Meyer et al. (2005), our study site was located in the peripheral quarters of a metropolitan area which counts for over 950 human inhabitants $/ \mathrm{km}^{2}$. Human disturbance and a highly busy beltway may have forced coypus to rest in their den setts in daylight hours, being more active at night. We are aware that several individuals have been killed with firearms in 2018 in this area (i.e., one-two years before our camera trapping study), which might have increased coypu activity in darkest hours (Gosling et al. 1980). In fact, in Great Britain, during the national coypu eradication programme, these rodents were mostly killed during daylight (Gosling et al. 1980).

Furthermore, the wolf, i.e., the main predator of the coypu in Italy (Ferretti et al. 2019) is present in this area, as also confirmed by three records in our camera-trap survey, and this may have helped bringing coypus to be more active when their detectability is the lowest, i.e., in darkest hours. Similarly, despite we have only winter data, coypus were strictly nocturnal also in a natural area (Site 3) located at the same latitude of the suburban one (i.e., similar winter temperatures), characterised by the presence of the wolf. We suggest that human pressure and predator presence have created a sort of "landscape of fear" for the coypu, which has adapted a mostly crepuscular/nocturnal behaviour in our suburban area to limit encounters with humans and to lower its detectability by natural predators (Tolon et al. 2009; Laundrè et al. 2010; Brivio et al. 2017). This would also reflect the nocturnal behaviour of the coypu in its native range (Palomares et al. 1994), where a number of potential predators occurs (e.g., the jaguar Panthera onca, the puma Puma concolor, the ocelot Leopardus pardalis, the oncilla L. tigrinus and six species of grey foxes Lycalopex spp.). Despite most predators being nocturnal in Europe (Mori et al. 2020b), which may suggest an increase in encounter rate with nocturnal coypus, this large rodent has also shown another temporal adaptation.

Moon phases influence the ranging behaviour of mammal species, with predators being mostly effective when some light occurs (e.g., the grey wolf: Theuerkauf et al. 2003), as their visual detection of prey is increased (Cozzi et al. 2012; 
Monterroso et al. 2013). As a response, prey species (e.g., rodents) tend to shift their ranging movements towards close or dark sites/nights (Alkon and Saltz 1988; Fattorini and Pokheral 2012; Upham and Hafner 2013). In Central Italy, the coypu is mostly preyed by the grey wolf in cold months (Ferretti et al. 2019), which may explain why this large rodent avoided bright moonlight only in winter, both in Site 2 and in Site 3. Consistently, in a natural area where the wolf is not present, besides diurnal behaviour, nocturnal bouts are concentrated in brightest moonlight, with coypus avoiding darkest nights. This fits with the behaviour of a mainly nocturnal semiaquatic rodent, the European beaver Castor fiber: this species, at night, select bright moonlight nights in absence of predators to better forage (Swinnen et al. 2015). Thus, our prediction (2) and (3) were only partially fulfilled, as other environmental constraints we did not consider in our analyses may shape the local behaviour of the coypu.

Eradication of the coypu could be possible no more for peninsular Italy; therefore, control programmes are ongoing to limit impacts on native biodiversity. Effectiveness of management strategies in the long-term could not circumvent ecological information on the target species, including patterns of activity rhythms, also to limit costs (cf. Bertolino et al. 2005; Bertolino and Viterbi 2010). The great ecological plasticity allowed coypus to adapt to a number of different environmental conditions ranging from natural ponds, to swamps, to riverine habitats in urban areas. Success of coypu control is related to local population density, social behaviour and spatiotemporal ecology, which should, therefore, be previously assessed.

Acknowledgements We thank two anonymous reviewers, who kindly took the time to improve our MS with their comments. We also thank Margherita Tisano for language revision.

Author contributions EM and LL conceived the study and carried out most analyses, AA organised the dataset and participated in analyses, FC and MM collected field data. All authors participated in writing the MS and approved the final version.

Funding This research did not receive any specific grant from funding agencies in the public, commercial, or not-for-profit sectors.

\section{Compliance with ethical standards}

Conflict of interest Authors certify that they have no affiliation with or involvement in any organization or entity with any financial or nonfinancial interest in the subject matter or materials discussed in this manuscript. Therefore, they have no conflict of interest to declare.

\section{References}

Alkon PU, Saltz D (1988) Influence of season and moonlight on temporal activity patterns of Italian crested porcupine (Hystrix indica). J Mamm 69:71-80
Andreoni A, Augugliaro C, Zozzoli R, Dartora F, Mori E (2020) Diel activity patterns and overlap between Eurasian red squirrel and Siberian chipmunks in native and introduced ranged. Ethol Ecol Evol. https://doi.org/10.1080/03949370.2020.1777211

Angelici C, Marini F, Battisti C, Bertolino S, Capizzi D, Monaco A (2012) Cumulative impact of rats and coypu on nesting waterbirds: first evidences from a small Mediterranean wetland (Central Italy). Vie et Milieu 62:137-141

Agapito Ludovici A, Cecere F, Bolpagni R, Bartoli M, Ferrari ME, Pizzetti L, Rancati S, Ravara S, Salvarani M, Toledo M (2012) Evoluzione recente (1980-2009) della Riserva Naturale Le Bine (CR-MN): sintesi dello stato delle conoscenze ecosistemiche. In: Umbria ARPA (ed) Tutela ambientale del Lago Trasimeno. ARPA Umbria Editions, Perugia, pp 323-333

Bellard C, Cassey P, Blackburn TM (2016) Alien species as a driver of recent extinctions. Biol Lett 12:20150623

Bertolino S, Cocchi R (2018) Piano di gestione nazionale della Nutria Myocastor coypus. Ministero dell'Ambiente e della Tutela del Territorio e del Mare, ISPRA. Technical Report, Roma and Ozzano nell'Emilia (Bologna), Italy

Bertolino S, Perrone A, Gola L (2005) Effectiveness of coypu control in small Italian wetland areas. Wildl Soc Bull 33:714-720

Bertolino S, Viterbi R (2010) Long-termcost-effectiveness of coypu (Myocastor coypus) control in Piedmont (Italy). Biol Invasions 12:2549-2558

Bertolino S, Angelici C, Monaco E, Monaco A, Capizzi D (2012) Interactions between coypu (Myocastor coypus) and bird nests in three Mediterranean wetlands of central Italy. Hystrix 22:333-339

Bertolino S, Sciandra C, Bosso L, Russo D, Lurz PW, Di Febbraro M (2020) Spatially explicit models as tools for implementing effective management strategies for invasive alien mammals. Mamm Rev 50:187-199

Berzi D (2015) Monitoraggio nuclei di lupo "problematici” provincia di Firenze. In: Vari A (eds) Monitoraggio del lupo in aree critiche della Toscana nell'ambito del progetto Misura C.2.2 azione A "Contributi per la realizzazione di iniziative e attività di monitoraggio faunistico". PRAF Regione Toscana 2012-2015. Firenze, pp 16-32

Brivio F, Grignolio S, Brogi R, Benazzi M, Bertolucci C, Apollonio M (2017) An analysis of intrinsic and extrinsic factors affecting the activity of a nocturnal species: the wild boar. Mamm Biol 84:73-81

Burton AC, Neilson E, Moreira D, Ladle A, Steenweg R, Fisher JT, Bayne E, Boutin S (2015) Wildlife camera trapping: a review and recommendations for linking surveys to ecological processes. J Appl Ecol 52:675-685

Capizzi D (2020) A review of mammal eradications on Mediterranean islands. Mamm Rev 50:124-135

Carnevali L, Lovari S, Monaco A, Mori E (2016) Nocturnal activity of a "diurnal" species, the northern chamois, in a predator-free Alpine area. Behav Proc 126:101-107

Carter J, Leonard BP (2002) A review of the literature on the worldwide distribution, spread of, and efforts to eradicate the coypu (Myocastor coypus). Wildl Soc Bull 30:162-175

Cecere F, Ravara S (2011) Check-list commentata degli Uccelli della Riserva Naturale Regionale le Bine (CR-MN) aggiornata a Settembre 2011. Pianura 26:25-46

Chabreck RH (1982) Daily activity of nutria in Louisiana. J Mamm 43:337-344

Chen Y, Xiao Z, Zhang L, Wang X, Li M, Xiang Z (2019) Activity rhythms of coexisting red serow and Chinese serow at Mt. Gaoligong as identified by camera traps. Animals 9:1071

Corriale MJ, Arias SM, Bò RF, Porini G (2006) Habitat-use patterns of the coypu Myocastor coypus in an urban wetland of its original distribution. Acta Theriol 51:295-302 
Corsini MT, Lovari S, Sonnino S (1995) Temporal activity patterns of crested porcupines Hystrix cristata. J Zool Lond 236:43-54

Cozzi G, Broekhuis F, McNutt JW, Turnbull LA, Macdonald DW, Schmid B (2012) Fear of the dark or dinner by moonlight? Reduced temporal partitioning among Africa's large carnivores. Ecology 93:2590-2599

Davis RA, Jenson OG (1960) A note on the distribution of coypus (Myocastor coypus) in Great Britain. J Anim Ecol 29:397

D’Adamo P, Guichòn ML, Bó RF, Cassini MH (2000) Habitat use by coypu Myocastor coypus in agro-systems of the Argentinean Pampas. Acta Theriol 45:25-34

Dias DM, Massara RL, de Campos CB, Rodrigues FHG (2019) Feline predator-prey relationships in a semiarid biome in Brazil. J Zool 307:282-291

Farina D, Cavitolo P (2016) Climate and land use changes as origin of the Water Cycle variations and sediment transport in Pesaro Urbino Province, Central and Eastern Italy. Acque Sotterranee Ital J Groundw 207:23-31

Fattorini N, Pokheral CP (2012) Activity and habitat selection of the Indian crested porcupine. Ethol Ecol Evol 24:377-387

Ferretti F, Lovari S, Mancino V, Burrini L, Rossa M (2019) Food habits of wolves and selection of wild ungulates in a prey-rich Mediterranean coastal area. Mamm Biol 99:119-127

Genovesi P (2011) Are we turning the tide? Eradications in times of crisis: how the global community is responding to biological invasions. Island Invasives Erad Manag 1:5-8

Giuntini S (2019) Alieni tra noi: percezione pubblica e tolleranza sociale verso i parrocchetti dal collare invasivi in Italia. Bachelor Thesis in Scienze Faunistiche, University of Florence, Florence, Italy

Gosling LM (1979) The twenty-four-hour activity cycle of captive coypus (Myocastor coypus). J Zool (Lond) 187:341-367

Gosling LM, Guyon GE, Wright KMH (1980) Diurnal activity of feral coypus (Myocastor coypus) during the cold winter of 1978-9. J Zool (Lond) 192:143-146

Lashley MA, Cove MV, Chitwood MC, Penido G, Gardner B, De Perno CS, Moorman CE (2018) Estimating wildlife activity curves: comparison of methods and sample size. Sci Rep 8:1-11

Laundrè JW, Hernàndez L, Ripple WJ (2010) The landscape of fear: ecological implications of being afraid. Open Ecol J 3:1-7

Lerone L, Carpaneto GM, Loy A (2015) Why camera trapping fail to detect a semi-aquatic mammal? Activation devices as possible cause. Wildl Soc Bull 39:193-196

Linkie M, Ridout MS (2011) Assessing tiger-prey interactions in Sumatran rainforests. J Zool 284:224-229

Lomnicki A (1957) The daily rhythm of activity in the nutria (Myocastor coypus Molina). Folia Biol 5:293-306

Lund U, Agostinelli C, Arai H, Gagliardi A, Portugues EG, Giunchi D, Irisson JO, Pocernich M, Rotolo F (2017) Package circular. https ://mirrors.ucr.ac.cr/CRAN. Accessed on 22 Mar 2020

MacArthur RA (1980) Daily and seasonal activity patterns of the muskrat Ondatra zibethicus as revealed by radiotelemetry. Ecogr 3:1-9

Mack RN, Simberloff D, Lonsdale WM, Evans H, Clout M, Bazzaz FA (2000) Biotic invasions: causes, epidemiology, global consequences, and control. Ecol Appl 10:689-710

Marini F, Gabrielli E, Montaudo L, Vecchi M, Santoro R, Battisti C, Carpaneto GM (2013) Diet of coypu (Myocastor coypus) in a Mediterranean coastal wetland: a possible impact on threatened rushbeds? Vie et Milieu 63:97-103

Mazza G, Tricarico E, Genovesi P, Gherardi F (2014) Biological invaders are threats to human health: an overview. Ethol Ecol Evol 26:112-129

Mazza G, Marraccini D, Mori E, Priori S, Marianelli L, Roversi PF, Gargani E (2019) Assessment of color response and activity rhythms of the invasive black planthopper Ricania speculum
(Walker, 1851) using sticky traps. Bull Entomol Res. https:// doi.org/10.1017/S000748531900083X

Ménard A, Agoulon A, L'Hostis M, Rondelaud D, Collard S, Chauvin A (2001) Myocastor coypus as a reservoir host of Fasciola hepatica in France. Vet Res 32:499-508

Meredith M, Ridout M (2014) Overview of the overlap package. https://cran.cs.wwu.edu/web/packages/overlap/vignettes/overl ap.pdf. Accessed on 23 Mar 2020

Meyer J, Klemann N, Halle S (2005) Diurnal activity patterns of coypu in an urban habitat. Acta Theriol 50:207-211

Mohr K, Vibe-Petersen S, Lau Jeppesen L, Bildsøe M, Leirs H (2003) Foraging of multimammate mice, Mastomys natalensis, under different predation pressure: cover, patch-dependent decisions and density-dependent GUDs. Oikos 100:459-468

Monterroso P, Alves PC, Ferreras P (2013) Catch me if you can: diel activity patterns of Mammalian prey and predators. Ethol 119:1-13

Monterroso P, Alves PC, Ferreras P (2014) Plasticity in circadian activity patterns of mesocarnivores in southwestern Europe: implications for species coexistence. Behav Ecol Sociobiol 68:1403-1417

Mori E, Nourisson DH, Lovari S, Romeo G, Sforzi A (2014) Selfdefence may not be enough: moonlight avoidance in a large, spiny rodent. J Zool 294:31-40

Mori E, Sangiovanni G, Corlatti L (2020a) Gimme shelter: the effects of rock and moonlight on occupancy and activity pattern of an endangered rodent, the garden dormouse Eliomys quercinus. Behav Proc 170:103999

Mori E, Bagnato S, Serroni P, Sangiuliano A, Rotondaro F, Marchianò V, Cascini V, Poerio L, Ferretti F (2020b) Spatiotemporal mechanisms of coexistence in an European mammal community in a protected area of southern Italy. J Zool 310:232-245

Nardoni S, Angelici MC, Mugnaini L, Mancianti F (2011) Prevalence of Toxoplasma gondii infection in Myocastor coypus in a protected Italian wetland. Paras Vectors 4:240

O'Connell AF, Nichols JD, Karanth KU (2011) Camera traps in animal ecology. Methods and analyses. Springer, New York

Palomares F, Bo R, Beltran JF, Villafae G, Moreno S (1994) Winter circadian activity pattern of free-ranging coypus in the Paranà River Delta, eastern Argentina. Acta Theriol 39:83-88

Panzacchi M, Bertolino S, Cocchi R, Genovesi P (2007) Population control of coypu Myocastor coypus in Italy compared to eradication in UK: a cost-benefit analysis. Wildl Biol 13:159-171

Patergnani M, Gras LM, Poglayen G, Gelli A, Pasqualucci F, Farina M, Stancampiano L (2010) Environmental influence on urban rodent bait consumption. J Pest Sci 83:347-359

Pontarini R, Lapini L, Molinari P (2019) A beaver from north-eastern Italy (Castor fiber: Castoridae: Rodentia). Gortania. Bot Zool 40:115-118

Prigioni C, Balestrieri A, Remonti L (2005) Food habits of the coypu, Myocastor coypus, and its impacts on aquatic vegetation in a freshwater habitat of NW Italy. Folia Zool 54:269-277

Ridout MS, Linkie M (2009) Estimating overlap of daily activity patterns from camera trap data. J Agric Biolog Environ Stat 14:322-337

Roviani D, Artioli P, Bertolino S (2020) Evaluating the effectiveness of footprint platforms to detect invasive mammals: coypu (Myocastor coypus) as a case study. Mamm Biol. https://doi.org/10.1007/ s42991-020-00021-1

Svihla A, Svihla R (1931) The Louisiana muskrat. J Mamm 12:12-28

Swinnen KR, Hughes NK, Leirs H (2015) Beaver (Castor fiber) activity patterns in a predator-free landscape. What is keeping them in the dark? Mamm Biol 80:477-483

Theuerkauf J, Jedrzejewski W, Schmidt K, Okarma H, Ruczynski S, Gula R (2003) Daily patterns and duration of wolf activity in the Bialowieza forest, Poland. J Mamm 84:243-253 
Tolon V, Dray S, Loison A, Zeileis A, Fischer C, Baubet E (2009) Responding to spatial and temporal variations in predation risk: space use of a game species in a changing landscape of fear. Can J Zool 87:1129-1137

Torretta E, Mosini A, Piana M, Tirozzi P, Serafini M, Puopolo F, Saino $\mathrm{N}$, Balestrieri A (2017) Time partitioning in mesocarnivore communities from different habitats of NW Italy: insights into martens' competitive abilities. Behaviour 154:241-266

Upham NS, Hafner JC (2013) Do nocturnal rodents in the Great Basin Desert avoid moonlight? J Mammal 94:59-72

Woods CA, Contreras L, Willner-Chapman G, Whidden HP (1992) Myocastor coypus. Mamm Species 398:1-8

Yoneda M (1983) Influence of red fox predation upon a local population of small rodents III. Seasonal changes in predation pressure, prey preference and predation effect. Appl Entomol Zool 18:1-10
Zanzani S, Di Cerbo AR, Gazzonis A, Epis S, Invernizzi A, Tagliabue S, Manfredi M (2016) Parasitic and bacterial infections of Myocastor coypus in a metropolitan area of Northwestern Italy. J Wildl Dis 52:126-130

Publisher's Note Springer Nature remains neutral with regard to jurisdictional claims in published maps and institutional affiliations. 